\title{
TUDOMÁNYTÖRTÉNET
}

\section{Emlékezés a 80 évvel ezelőtt elhunyt Gombocz Zoltánra*}

1. A Magyar Nyelvtudományi Társaság legnevesebb tagjára emlékezik abból az alkalomból, hogy Gombocz Zoltán nyolcvan évvel ezelőtt hunyt el. Arra a társasági tagunkra emlékezünk, akiröl NÉMETH GYULA írta, hogy „,fiatal kora óta - fötámasza [volt] a Magyar Nyelvtudományi Társaságnak" (1972: 238). Való igaz, hiszen alapító tagja volt, s kezdettől fontos tisztségeket (jegyző, titkár, alelnök) töltött be a Társaság közvetlen vezetőségében, s úgyszintén kezdettől fogva mindvégig társszerkesztője volt a Magyar Nyelvnek - kolozsvári egyetemi tanári éveinek a kivételével (1. SzATHMÁRI 2015: 41, 207-209). MELICH egyértelmüen fogalmazott: a Magyar Nyelv „legnagyobb súlyú és értékü munkatársa” Gombocz volt (MNy. 1935: 200). Csak róla mondható el Társaságunk tagjai közül, hogy személyéről és életmüvéről csaknem félszáz értékelés jelent meg magyar, francia, német, angol, svéd, finn és észt nyelven. A magyar nyelvtudomány történetének a 19/20. század fordulóját követő fontos szakaszában a Magyar Nyelvtudományi Társaság, illetőleg Gombocz megjelenése és tevékenysége volt a legfőbb garancia a magyar nyelvtudomány professzionalizálódására, továbbfejlődésére. S ami úgyszintén kiemelendő: „Gombocz munkássága nem egyszerüen mérhető nemzetközi mércével, hanem egyenesen azzal mérendő: neve a XX. század eleji Európában a szakma minden magára valamit adó képviselője számára ismert volt” (FEHÉR 2011: 74).

Gombocz Zoltán tudományos pályája négy intézménnyel fonódott össze szorosan. A Budapesti Tudományegyetemmel, amelynek előbb magyar-francia szakos hallgatója, majd professzora, tanszékvezetője és a Bölcsészkar dékánja is volt. Az Eötvös Collegiummal (hivatalos nevén: Báró Eötvös József Collegium), amelynek kiemelkedő tehetségü tagja, majd elsőként a collegisták közül tanára és legendás igazgatója is volt (1. még GARAI 2014: 195-246). Társaságunkkal, ahogy erről már szóltam. S végül a Magyar Tudományos Akadémiával, amelynek levelező tagjává 28 éves korában választották meg. Később osztályelnök lett s igazgató tag is. S ő volt az egyetlen nyelvész, akinek a neve a következő összefüggésben is fölmerült: ,,a két világháború közti Akadémia igazi képviselőinek ma Bartók Bélát és Gombocz Zoltánt [...] látjuk” (SŐTÉR véleménye, idézi HARMATTA 1977: 393).

Gombocz életművének részletes és kompetens értékelését az utókor elvégezte már. Egyrészt NÉMETH GYULA tudománytörténeti kismonográfiájában 1972-ben. Születésének centenáriumán, 1977-ben megrendezett tudományos ülésszak neves elöadói pedig részletesen, szakterületi bontásban tették mérlegre Gombocz nyelvtudományi tevékenységét (1. BENKÖ szerk. 1977). A Gombocz életéről és pályaképéről készült legújabb, részletes jegyzetapparátust is felvonultató összefoglalás 2006-ban jelent meg KICSI SÁNDOR ANDRÁS tollából. Gomboczról mint az Eötvös Collegium igazgatójáról collegiumi levéltári források bevonásával GARAI IMRE írt újabban és legrészletesebben (2004). Az érdeklődőknek

* A Magyar Nyelvtudományi Társaság felolvasó ülésén 2015. május 26-án az ELTE Bölcsészkarán elhangzott előadás némileg módosított változata.

DOI: 10.18349/MagyarNyelv.2015.4.465 
van tehát mihez fordulniuk (de bölcsen teszik, ha GOMBOCz írásait is olvassák, ugyanis bőven szolgálnak tanulsággal).

A jelen alkalom a megemlékezésé. Ezért csak bizonyos képek felvillantása, bizonyos tudománytörténeti tények említése, s a Gomboczot ismerő pályatársak és tanítványok visszaemlékezései közötti, idézetekkel alátámasztott tallózás lehet szándékom.

Gombocz munkásságának a tárgyilagos megítéléséhez megvolt az időbeli távlat már 1972-ben is. Ma még inkább megvan. A mi nemzedékünk tagjai már nem szólíthatnak meg senkit, aki Gomboczról személyes hitelességgel beszélhetne nekünk. Számunkra a leghitelesebb források nyomtatásban megjelent írásai. Személyéről pedig az őt jól ismerő munkatársak, tanítványok visszaemlékezései, illetőleg a Gombocz-legendárium hozzánk eljutó történet-elbeszélései alapján tájékozódhatunk. A rövidesen idézendő visszaemlékezéseket hallva, az utókor szenvtelenségéből kiindulva gondolhatnánk, hogy a Gomboczra visszaemlékezők elfogultak voltak, hogy bizony sürün túlzásokba is estek, amikor róla írtak. Lehetséges. Ezt azonban cáfolni látszik az iránta a visszaemlékező sorokból is sugárzó tisztelet, amely önmagában is visszatarthatta a visszaemlékezőket attól, hogy hamis, tapasztalataiknak ellentmondó szó kerüljön emlékező soraikba. Gomboczról a tanítványok meggyőződését így foglalta szavakba 1977-ben TOMPA JÓzSEF: „,csak egyet tehetünk már: nem felejtjük el, hogy ő volt a Mérték" (1977: 414). Mi pedig csak azt tehetjük, hogy a viszszaemlékezéseket is komolyan vesszük.

Gombocz munkássága nyolcvan évvel ezelőtt lezárult. Sem utóélete, sem pedig hatástörténete azonban nem. Ma is lehet tanulni müveiből és példamutatásából (1. például KÓSA 2007: 107). Igaz, hatása az idő múlásával szükségszerüen és természetes módon egyre inkább csökken (vö. például: amit Gombocz „,müvelődéspolitikusként tett a finnugrisztikáért, azt elfelejtette, illetőleg el fogja feledni az utókor”: LAKÓ 1977: 434). Gombocz tudománytörténeti nagysága azonban vitathatatlan, s jövőben is az marad. Ám minden kétséget kizáró jelentősége ellenére sem szabad őt szoborrá merevíteni. Éppen ellenkezőleg! A miénk is tehát a gomboczi életművel kapcsolatos kérdezés magától értődő joga és továbbgondolásának lehetősége, sőt kötelessége is.

2. „Gombocz Zoltán a született, az ellenállás, erőfeszítés nélkül hódító és mindenkitől kivételesnek elismert tehetség iskolapéldája” (ZSIRAI 1935: V) volt kora ifjúságától fogva. 1877-ben született Sopronban és 1935-ben hunyt el Budapesten. 58 évet élt - de úgy is fogalmazhatnék: csak 58 évet élt. De amilyen tüneményes volt berobbanása a magyar nyelvtudományba, olyan titokzatos volt élete utolsó szakaszában jelentkező rezignációja. Életének záróakkordja a fővárosi egyetem bölcsészkarához kötődik. 1935. május elsején a kari tanácsi ülésén Gombocz a Kar dékánjaként elnökölt. S ezen olyasmi történt, amire - szokatlan volta miatt - fölfigyeltek a jelenlévők. Gombocz egy névlajstrom neveit olvasta (rektori elektori választás volt), s a Domanovszky Sándor nevet - s ez teljesen szokatlan volt tőle - kezdte újra mondani. Mondta is, de csak a családnév lassuló kiejtéséig jutott. A szem- és fültanú NÉMETH GYULA így emlékezett vissza: ,a Sándor szót már nem mondta ki másodszor, lehanyatlott a feje, aztán ő maga is, - meghalt. Bekövetkezett az óhajtott szép halál, hirtelen, munka közben. Mi továbbmentünk, sírva, megdöbbenve, nélküle” (1972: 240).

3. Gombocz halála az akkori magyar humán értelmiségi elitet megdöbbentette. HARMATTA szerint „Gombocz halála annak idején olyan visszhangot váltott ki tudományos 
közvéleményünkben és azon túl is, amilyenre azóta sem találunk példát” (i. h.). Vajon miért? KOSÁRY DOMOKOS (tehát nem nyelvész) 2002-ben írt szavai adják meg a magyarázatot: „Gombocz nemcsak a magyar nyelvtudománynak, hanem az egész akkori hazai tudományosságnak is kétségtelenül egyik legkiemelkedőbb személyisége volt” (2002: 238). A nyelvészek jól tudják, Gombocz Zoltán a magyar nyelvtudomány mindmáig legegyetemesebb képviselőjeként, legszélesebb látókörü, legnagyobb hatású alakjaként tudósi és emberi nagyságával egyaránt kiemelkedett kortársai közül. Nemcsak kivételes tudása, ragyogó kritikai érzéke, lenyügözően széles müveltsége és nemes embersége említtetik újra és újra a visszaemlékezésekben, hanem különös személyes varázsa is, amely rabul ejtett tanítványt és munkatársat itthon és külföldön egyaránt. 1935-ös nekrológjában ZSIRAI MIKLÓS azt írta róla: „Történeti tekintélyként tiszteltük, mikor még köztünk járt-kelt: eleven valóságként él szívünkben, mikor immár történetté magasztosult” (1935: XVI). 1955ben pedig így kezdte a rá való emlékezést egyik volt tanítványa, KovALOVSZKY MIKLÓs: „Húsz éve halt meg Gombocz Zoltán. Emlékezések sora, vers és regény idézte akkor alakját és szellemét. Ez a gyászkar nem a szokásos halotti búcsúztató volt. Sajátos dallama valami rendkívüli veszteség fájdalmát érezteti. Még a legtárgyilagosabb méltatásokból is az emberi és szellemi nagyság misztikuma árad, s ezt megérzik azok is, akik már csak az alakját burkoló legendákból és munkáinak csillogó értelmű soraiból ismerik Gombocz Zoltánt. Bocsássanak meg, hogy tudósról emlékezvén, húsz év múltán magam is csak az emlékezés lírájával és az érzelem ellágyulásával tudok közeledni feléje. Nem tehetek másként, hamis volna minden más hang, amelyet róla kiejtek. Az ifjúság nagy élményei között ő adta nekünk talán a legnagyobbat, de kétségtelenül a legmaradandóbbat: a szellem varázslatos kalandját, a tudás ihletését” (1955: 3). ZSIRAI szerint „Gombocznak látnia kellett munkássága hatását, alapvető értékét, fejlődéstörténeti [tudománytörténeti] jelentőségét. Mutatni azonban sohasem mutatta, éreztetni azonban senkivel sem éreztette, mert embernek éppolyan volt, mint tudósnak: nagyvonalú, nemes és finoman tartózkodó [...] Keresetlen, közvetlen, lebilincselően kedves volt: megvetette a frázist, lenézte a »fesz és pöf« [feszítő és pöffeszkedő] bajnokait. Szerette fajtáját, de nem hivalkodott vele, szerette munkatársait, de csak hátuk mögött dicsérte őket, szerette tanítványait, de sokat kívánt tőlük. A megtestesült jóindulat, a magától kínálkozó szolgálatkészség volt” (1935: XVI).

KORNIS GYULA úgy vélte, hogy Gombocz ,,a nagy összefüggéseket rögtön megpillantó fölényes szintétikus elme” volt. ECKHARDT SÁNDOR szerint Gomboczot „,zseniálisan tiszta ítélőképesség”, KATONA JENŐ szerint pedig ,a müveltség szinte kábító sokoldalúsága és mélysége”, illetve „előadásmódjának kristályos tisztasága és alapossággal párosult eleganciája” jellemezte. ALO RAUN úgy tapasztalta, hogy „előadásai [...] utolérhetetlen tartalmi és formai világosságukkal nyerték meg hallgatói tetszését" (idézi HARMATTA 2002: 238-239). SÖTÉR ISTVÁN szerint Gombocz munkái „,szinte művészi ökonómiával megépített” müvek, s hogy tanulmányai „leginkább matematikai értekezésekre emlékeztetnek, szabatos szerkezetükkel, szükszavúságukkal, kristályszerü áttetszőségükkel”. KoRNIs úgy vélte, hogy Gombocz ,örökös szellemi mozgékonyságban élt”, HoRVÁTH JÓzSEF szerint pedig ,,minden új kutatási területen csak addig időzött, amíg kombinatív-intuitív elméje rá nem lelt a punctum saliens-ra” (idézi HARMATTA 2002: 239). HARMATTA szerint „Nagy tudós egyéniségének jelenléte a körülötte élő tudós társadalmat sohasem hagyta megnyugodni: mindig továbblépésre, fejlődésre, magas színvonal elérésére késztette" (1977: 395). KosÁrY DOMOKOS úgy emlékezett vissza, hogy Gomboczot „mindenki nagynak 
látta [...] mindenki szerette" (idézi HARMATTA 1997: 392). NÉMETH GYULA azt írta róla: „kritikai éleslátás és tudásának szédítő részletessége [...], a tervszerüen megszerzett egyetemes mủveltség, az egyetemes látás jellemzi” (1972: 13, 27). KOSZTOLÁNYI 1925-ben, a 47 éves tudóssal lakásán készült s a Pesti Hírlapban megjelent interjúját így fejezte be: „észreveszem a szavak etimonjai mellett a három cserép muskátlit is, mely, míg csevegünk, egy háncsasztalon állott előttünk, az élő természet mosolyát hintve szét, és kimenet látom a fényt is, mely rézsút sugarával bearanyozza a tudós szobáját, a fényt, mely elözönli szellemét" (1925/1996: 332). Sauvageot emlékirataiban így emlékezik a Gomboczcal történt megismerkedésére: „Nem is tudom, mi volt a varázsa ennek az embernek [...] Az első pillanattól éreztem, hogy rendkívüli személyiség” (1988: 30).

Gomboczról mint az Eötvös Collegium legendás igazgatójáról így írt NÉMETH GYULA: „Szerette az ifjúságot [...] S a fiatalság rajongott érte. A Kollégiumban diákkora óta glória övezte [...] s ennek a glóriának a fénye messzire világított” (1972: 208). SőTÉR pedig így vallott róla: „Ma már tudom, hogy a kollégium mást és sokkal kevesebbet jelentett volna, ha nem az a férfi áll az élén, akinek nevéhez életünk leggazdagabb és legszerencsésebb éveinek emléke füződik. Ez a férfi a legnagyobb magyar tudósok egyike volt, s ö ízleltette meg velünk a szellemnek [...] magas szenvedélyeit [...] Hitte és hirdette az ihletet, a szerelemmel is felérő szenvedélyt, melyet ki kell verekednünk a tudománytól, hisz nélküle üres, fakó időtöltés a munkánk [...] A legnagyobb nevelő volt, akihez valaha is közünk volt: hol egy törvényszerüségből, hol egy Wagner opera nyitányából, hol egy bor ízéből vezetett rá bennünket arra, amit meg akart ismertetni velünk. Mert mindig csak az életre tanított [...] A gomboczi eszmény valójában a minőség eszménye, olyan minőségé, amely erkölcsöt is jelent. A legtöbbet és a legjobbat adni magunkból, másoknak, és másoktól is ugyanezt elvárni: ez volt Gombocz Zoltán nevelői elve [...] a Kollégiumban rendtartás nélkül is rend, szabadon és önként vállalt fegyelem, munkaerkölcs uralkodott [...] megvetette a dilettantizmust, sőt az »életmüvészetet« is. Ekkorra tudta már, hogy az igaz életörömöt csak áldozatok és munkák árán lehet elérni, olyan szabadságban, melyet leginkább az önzetlenség jellemez" (1977: 388).

4. Gombocz szemléletében és munkásságában általános nyelvészet és speciális nyelvészet, elmélet és empíria az akkori magyar nyelvtudományban, de talán azóta is példátlan szerves egységbe, teljes harmóniába olvadt. Nem különítette el őket: „a tudományos kérdéseket mindig az összefüggések nagy távlatából, az egyetemesség tisztult magaslatáról nézte" (ZSIRAI 1935: XV). Párját ritkítóan sokoldalú volt a maga tudományában. Több speciális nyelvészetet is művelt: otthon volt a turkológiában, a romanisztikában, a germanisztikában és a finnugrisztikában is úgy, hogy fő munkaterülete a magyar nyelvészet, a nyelvtörténet volt. Egyetemi magántanárrá általános fonetikából és finnugor hangtanból habilitálták. Társasági közgyülési előadásai események, fontos referenciapontok voltak kora magyar nyelvtudományában (1907, 1921, 1925, 1929, 1931, 1934, 1. SzATHMÁRI 2015: 209-210). Érdemes felsorolni előadásainak a címét: A jelenkori nyelvészet alapelvei, Nyelvtörténet és lélektan, Hangutánzás és nyelvtörténet, A nyelvek egysége, Képzettársítás és jelentésváltozás, Változás és törvény a nyelvtudományban, Leíró nyelvtan, történeti nyelvtan, Nyelvtörténeti módszertan, Jelentéstan, Nyelvhelyesség és nyelvtudomány, Mi a mondattan? Funkcionális nyelvszemlélet. 1934-es közgyülési elöadásának bevezetője valóságos tudományos ars poetica, az alkotó tudós vallomása kutatási elveiről. Arról be- 
szélt ugyanis, hogy ,,a megfigyelt nyelvi tényeknek elfogadható értelmezésére való törekvés miképen terelte figyelmemet az utóbbi tizenöt esztendőben egyre fokozódó mértékben a funkciófogalom fontosságára, mindenekelött a jelentéstanban, majd a syntaxisban, s hogy miképen kapcsolódtak össze lassan-lassan eleinte töredékes megfigyeléseim, gondolataim az egész nyelvi életet átfogó rendszerré, a nyelvi élet olyan felfogásává, amelyet előadásom címében funkcionális nyelvszemléletnek neveztem" (1934: 1). Idekapcsolódóan ZSIRAItól idézek megint: „Ö, aki a részben is az egészet érezte, a formában is a létrehozó erőt kereste: a nyelvi tényeket [...] az élet mintázatának, a müvelödési történeti folyamatok függvényének fogta föl” (1935: XIV). Gombocz véleménye az volt, hogy a nyelvet nem elég csak mint elvonatkoztatott jelrendszert vizsgálni. Azt írta: „Az első és legfontosabb dolog [...] nem választani el a nyelvet a beszélő embertől” (1989: 8). Illetőleg: „Mi nem egy készen kapott filozófiai elméletre alapítjuk magyarázatainkat, hanem a nyelvi élet gondos megfigyelésére elméletünket. Nem a nyelvtörténet nemismerése tesz bennünket merésszé, hanem éppen a történeti fejlődés lelkiismeretes vizsgálata veti meg szilárd alapjait magyarázatainknak” (1913: 391). Elmélet és empíria viszonyát így látta 1898-ban: „A tudományos kutatásban a feltevések és elméletek értékét gyakorlati használhatóságuk bizonyítja. Legértékesebb feltevések a munkahipotézisek. Így van ez a nyelvtudományban is" (1898: 7).

GOMBOCZ 1908-ben a hazai nyelvjáráskutatásban új módszertani követelményt fogalmazott meg. Azt, hogy a nyelvjárásokat „önálló nyelvegység”-ként kell leírni (MNy. 1909: 47; a nyelvváltozatok rendszertani önállóságának a tételezése strukturalista szemléletböl fakad). A „baj” az volt, hogy Gombocz ezt a módszertani elvárást egy választmányi ülésen, titkári jelentésében fogalmazta meg. Tehát nem kifejtve, nem önálló cikkben. Minthogy pedig választmányi jegyzőkönyveket, sőt közgyülési beszámolókat sem szokás olvasni - kivételek a társaságtörténettel foglalkozók -, a gomboczi vélemény lényegében ismeretlen maradt. (Egy kivétellel: CSÜRY BÁLINT a Szamosháti szótár anyagát Gombocz javaslata szerint gyüjtötte és kidolgozásában is követte: SzamSz. 1: 6.) Igaz, ez a gomboczi elvárás az akkor általános gyakorlattal, amely szerint a nyelvjárási leírások nyelvjárási különlegességek taxonomikus listázásából álltak, élesen szembe ment (gondoljunk a Nyelvészeti Füzetek nyelvjárási „monográfiái”-ra). Meglepőnek tünhet, de a Magyar Nyelvtudományi Társaság nyelvjárási kérdöívére beküldött feleletekből Gombocz állította össze s szerkesztette meg a Szinnyei-féle Magyar tájszótár (MTsz.) két kötetének kiegészítő füzetét (GOMBOCZ 1910). Kiderült, hogy a nyelvjárási szókészlettel való foglalkozás számára is többrendbeli haszonnal járt, mindenek elött etimológiai vizsgálataihoz (a Magyar Etymologiai Szótár szócikkeire gondoljunk), továbbá az onomatopoézis szerepének a megítéléséhez, s ezzel összefüggésben egy elvi jelentőségü, 1913-as tanulmány megírásához (Hangutánzás és nyelvtörténet), amely tanulmány nálunk negyven év múltán a hangutánzó-hangulatfestő szavak módszeres etimológiai vizsgálata megindulásának fő hivatkozási alapjául szolgált (BENKÖ 1954: 255), s volt fontos A magyar nyelv történeti-etimológiai szótára munkálatai során is (BENKŐ 1977: 405).

Pályája kezdetén Gombocz még úgy látta, hogy a nyelvtudománynak nincsenek ahisztorikus diszciplínái. Ezen azonban hamar túllépett. S ő lett a szinkrón leíró kutatások sürgetője. Elsőként ő látta világosan a magyar nyelvtudományban, hogy „,a nyelvtörténeti kutatás nem kizárja, hanem fölhasználja, sőt bizonyos értelemben magába is foglalja a szinkrón leíró kutatások módszerét és eredményeit" (BENKŐ 2010: 37).

Gombocz számára világos volt, hogy a nyelvtudományt a puszta adatok nem önmagukban érdeklik, hanem elsősorban a közöttük levő viszonyok foglalkoztatják, illetőleg 
mindaz, ami túlmutat az adatokon. A Kosztolányinak 1925-ben adott interjúban ezt mondta: „Vége annak a nagyon is »pozitív« nyelvészkedésnek, mely csak az anyaggyüjtéssel törődött, folyton szavakat hordott, talicskázott [...]. Ki tagadja, hogy kell az adatgyüjtés is? De ez csak eszköz" (KosZTOLÁNYI 1925/1996: 330). Ebben az interjúban mondta azt is, hogy a tudomány művelőinek időről-időre el kell gondolkodniuk tudományuk alapkérdéseiről.

Fölmerül a kérdés: az elméleti érdeklődésü, általános nyelvészeti vénájú, több irányba is tájékozódó Gombocz hogyan viszonyult a Melich Jánossal közösen készülő etimológiai szótár társszerzőjeként az etimológiák írásának nem szünő penzum-kötelezettségéhez? A Magyar Etymologiai Szótár szócikkeinek elkészítése ugyanis sok időt igénylő, monotonsága miatt nyilván nem ritkán száraznak is tünő filológiai munkával járt. Erről azonban semmit sem tudunk. Munkamegosztásukról azt tudjuk, amit MELICHtől tudhatunk. Ö a következőt írta: „Rendesen én dolgoztam ki a cikkeket, s Gombocz gondos keze, erős, fegyelmezett itélőképessége vagy helybenhagyta, vagy átírta, s aztán újból hozzám került a kézirat, átolvastam, nyomdába adtam" (1936: 76; Gombocz és Melich együttes jellemzésére 1. KISS LAJOS 1995: 66-68). Arról sincs tudomásunk, mikor vált világossá számukra, hogy a tervezett etimológiai szótár megírása két ember erejét meghaladó vállalkozás, hiszen ,egy nagy magyar etimológiai szótár elkészítésének mércéjét szinte megközelíthetetlen magasságra” emelték (BENKŐ 1962: 264).

Modern világunkban a ,leg”-eknek nagy hírértéke van. Gombocz több tekintetben is „leg” volt. Néhányat meg is említek. 1. Senki annyi területet átfogva és olyan mélységben nem müvelte a magyar nyelvtudományt, mint ő. 2. Korának legtöbbet hivatkozott magyar nyelvésze volt. De az elhunyt magyar nyelvészek közül a legtöbb hivatkozás - 2015-böl visszatekintve is - rá vonatkozik. 3. A legszélesebb pedagógiai hatású magyar nyelvész volt annak ellenére, hogy nem nevelt a szó mai értelmében tanítványokat (1. NÉMETH 1972: 234; BENKÖ 1977: 409). „Gombocz előadóterme zsúfolva volt, gyakorlatokat és tanszéki megbeszéléseket is tartott, de hiányzott belőle Simonyi közvetlensége, Melich romboló és építő kritikája" (NÉMETH 1972: 228). 4. Kapcsolatban állt írókkal, költőkkel is. Ezért is fogalmazódott meg vele kapcsolatban, hogy „Tudomány müvészetre nem tett akkora hatást azóta sem Magyarországon, mint Gombocz nyelvészete a nyelv müvészeire" (SIMONCSICS 2005: 84). 5. Az Eötvös Collegium történetében ő volt az első collegista, akit a Collegium meghívott tanárának (közvetlenül az egyetem elvégzése után). 6. Ö volt az első volt Eötvös collegista, aki a Collegium igazgatója lett. 7. Annyi legenda egyetlen más magyar nyelvészt sem övezett és övez, mint őt. Sajnálatos, hogy ezek nincsenek felgyüjtve. Ma még él néhány volt Eötvös collegista (a régi, az 1949-ben megszüntetett Collegium tagjaira gondolok), elsősorban őket kellene megkérdezni ez ügyben, s össze kellene gyüjteni az írásban megjelent történeteket is.

Amilyenek tanulmányai voltak (logikus felépítés, világos okfejtés, ökonomikus rövidség), olyan volt beszéde is. NÉMETH GYULA szerint „,minden mondata logikus, kicsiszolt, hibátlan volt. Állva beszélt, minden szónokiasság nélkül, egyszerűen, teljes biztossággal” (1972: 229). A tanítvány TOMPA JÓZSEF így emlékezett vissza: „,enyhén nyugat-dunántúlias árnyalatú müvelt magyar kiejtését is élvezet volt figyelnünk" (in: BENKŐ szerk. 1977: 410). HEVESI ANDRÁs szerint „fogalmazása szóban és írásban [...] maradéktalanul tökéletes volt [...]. Tudományos prózája [...] megérdemelné, hogy helyet kapjon az iskolai stilisztikákban” (1935: 489). Érthető ezek után Gombocz kritikus véleménye: „Magyarországon az emberek nem tudják magukat kifejezni; nem azt írják, amit akarnak” (HEVESI 1935: 489). Hogy 
ez mennyiben volt a tudománnyal foglalkozók kritikája is, nem tudhatjuk. Említésre méltó, hogy kézírására a kalligrafikus írásmód volt jellemző. Szépen s olvashatóan írt. Nevét is mindig így írta, lett légyen szó egyetemi indexről, privát levélröl vagy levelezőlapról. KoszTOLÁNYI „rajzos, nyugodt betük”-et emleget Gombocz írásáról szólva (1925/1996: 330).

Gombocz „munkássága - elsősorban SAUSSURE hatására [akinek a tanítványai által összeállított Cours de linguistique générale címü, korszakos jelentőségü munkájáról 1924ben írt jelentőségét kiemelő ismertetést Gombocz] - két nyelvtudományi paradigma, a történeti-összehasonlító és a strukturalista határára esik" (KICSI 2006: 44). A korszerüség iránti érzéke vitte Gomboczot az új utak irányába, s nem tudjuk, mire jutott volna, ha elkészülhetett volna tervezett funkcionális nyelvtanával. Úgy vélem, élete utolsó évtizedében bekövetkezett „,bizonyos értelemben vett fásultsága” (KICSI 2006: 42) mögött több ok összetett hatása, mindenekelőtt pedig egészségi állapotának a gyengülése állt. Az azonban, hogy nem készülhetett el tervezett funkcionális leírása, a magyar nyelvtudománynak kétség kívül igen nagy kára. Úgyszintén nagy kár származott a magyar nyelvtudományra nézve integratív személyiségének a hiányából is (1. SIMONCSICS 2005: 67).

5. Ritkán említik, de érdemes tudni: Gombocz a politikával szemben mindig kritikus volt. SÖTÉR szerint „Korának társadalmi kérdéseit az Eötvös Kollégium [Collegium] fiataljainak közvetítésével fogja fel [...]. Nemzeti, de nacionalizmustól mentes humanista embereszményt testesített meg [...], olyan eszményt, mely leginkább Kodály Zoltánnal és Horváth Jánossal rokonította. Ök hárman sok tekintetben kiegészítették és folytatták egymás szerepét és életművét" (1977: 388; 1. még KOROMPAY H. 2011: 22). Arról a szellemi körről van tehát szó, amelynek legkiválóbb tagjai az Eötvös Collegium első, nagy nemzedékéhez tartoztak. A századforduló történései, majd különösen az I. világháború következményei miatt az önismeret és a felelős erkölcsi tudatosság normái magyar értelmiségi körökben tagadhatatlanul élesen időszerüek voltak. Ezért is mondhatjuk, hogy az említettek munkássága egy széttaposott és megrendült ország szellemi talpra állítási kísérletének is része volt. Nehéz persze, ha egyáltalán lehetséges Gombocz nemzedékének a helyzetébe képzelni magunkat. Mégis említésre méltó: Trianon Gomboczot is mélyen érintette, szülővárosának, a későbbi ,leghüségesebb város”-nak, Sopronnak a magyar szempontból végül is megnyugtatóan végződő elcsatolási kálváriája miatt különösen is. Tudvalévő az is, hogy kolozsvári egyetemi tanári tevékenységének Erdély elcsatolása vetett véget (a Kosztolányi-interjúban ez a kifejezés szerepel: „elkergették a kolozsvári egyetemről": 1925/1996: 330). Az 1920-as békediktátumot igazságtalannak tartotta, de tudta, hogy a magyar politikai elit súlyos hibái is szerepet játszottak benne. Amikor a Magyar Nyelvtudományi Társaság a vesztes háború következtében az anyagi ellehetetlenülés közelébe került, GOMBOCZ keserüen és bírálóan mondta ki 1922. évi titkári jelentésében: „nem tudom elhinni, hogy a magyar közönség és Társulatunk tagjai [...] belenyugodhassanak abba, hogy egy Társulat, amely [...] buzgón és önzetlenül [...] szolgálta a nemzeti nyelv és a magyar tudomány ügyét, csúfosan kimúljon az annyiszor hangoztatott magyar kultúrfölény nagyobb dicsőségére" (MNy. 1923: 103). SAUVAGEOT ezt írja visszaemlékezésében (az idézetet magyar fordításban megjelent memoárkötetéből veszem): „Késő éjszakába nyúló estéket töltöttem Gombocz Zoltánnal [...] a végeérhetetlen beszélgetéseknek [...] annyit [oly sokat] köszönhettem” (1988: 384), „[...] Az elutazásom elötti napon Gombocz Zoltán meghívott ebédre a Gellértbe [...]. Hosszasan elbeszélgettünk [...], azt 
mondta nekem: »Számítunk önre. Legyen a mi elöretolt őrszemünk odaát!« Azt feleltem: »Bízhatik bennem, de tartok tőle, hogy nem sokat tehetek«" (1988: 391). Nagy tekintélye miatt „Gomboczra hallgatott az establishment (mert azt hitték, hogy olyan, mint ők), de bízott benne a rebellis ifjúság is (mert ők tudták, hogy nem)" (SIMONCSICS 2005: 67). Megemlítem, hogy például Bethlen István miniszterelnök is levélben fordult hozzá 1927ben (GARAI 2014: 468). NÉMETH GYULÁtól idézek újra: „1932 májusában a rendőrség kommunista »összeesküvést« fedezett fel a Kollégiumban. Nagy volt a baj, de Gombocz megbirkózott vele [...] egyszer csak arra ébredtünk, hogy a Kollégiumot fenyegető veszedelem elmúlt" (210-211). Jellemző kortörténeti adalék Gombocz utóéletéhez 1948-ból: ez év novemberére, amikor Révai József és Lukács György látogatást tett a Collegiumban, a falakról eltünt Bartoniek Gézának (a Collegium első igazgatójának), Eötvös Lorándnak és Gombocz Zoltánnak a portréja (GARAI 2014: 420)...

Egybehangzó a vélekedés, hogy Gomboczot tehetsége, vele való sáfárkodása, fölkészülésének minősége és alapossága, nemkülönben a családi és az iskolai környezet (a nevezetes soproni evangélikus Líceum) lendítő ereje együttesen arra predestinálták, hogy ragyogó pályát fusson be. Ezt a valóban ragyogó pályafutást - talán így természetes - titkok is övezték. Erre szinte mindenki utalt, aki ismerte őt. ZSIRAI MIKLÓs szerint például bármennyire kedves személyiség is volt, „lelke legbelsejébe nem engedett bepillantani” (1935: XVI). A magyar tudományosságra gyakorolt hatását KORNIS GYULA Gombocznak „,a helyes kérdéseket [...] látó titokzatos” ösztönével magyarázta. HoRVÁTH JózSEF szerint Gombocz „nem volt titkolódzó, s mégis titokzatos” volt. SÖTÉR megerősíti ezt: „élete többé-kevésbé misztérium volt számunkra" (idézi HARMATTA 2002: 238). NÉMETH GYULA így írt Gombocz életéről: „Munkás, vidám, ragyogó emberi élet, - a mélyén a legsúlyosabb pesszimizmussal" (1972: 209). Elismerés övezte tehát - itthon és külföldön egyaránt. De ötven éves sem volt még, amikor a rezignáció jelei mutatkoztak nála. Mi történt? Kicsi, de sokat mondó adalék lehet, ami vele Finnországban esett. A finn nyelvészek körében is jól ismert, nagytekintélyü tudós tagja volt a Klebelsberg vezette, 1930-ban Suomiba utazó magyar kulturális küldöttségnek (NÉMETH 1972: 225, 236). Finn barátai nagy örömmel fogadták Gomboczot, s amikor gratuláltak neki a számos elismeréshez, a válasz tőle az volt: igen, de ennek nagy ára van: az édes ifjúság. Egyik volt éles szemü, nem nyelvész tanítványa szerint Gombocz utolsó éveiben sem volt hütlen önmagához, hiszen ,élete utolsó tíz éve is a módszer diadala volt: minden jelenséget oly pontosan elszigetelő [elkülönítő] eljárásával a maga jogos helyére szorította vissza a tudományt" (HEVESI 1935: 490). SÖTÉR ISTVÁN, aki jól ismerte Gomboczot, bizonyára helyes következtésre jutott, amikor azt írta: „Aszkézisben eltelt ifjúsága elmúltával, az élete utolsó szakaszába lépett Gombocz Zoltán későn és tragikusan érezte át, hogy mit vesztett el, s az élet micsoda örömeiről és tapasztalatairól mondott le [...]. Legkedvesebb operája volt a Mesterdalnokok, a rezignációnak és a tavasznak ez a színpompás, zenei találkozása. Talán magára ismert Hans Sachs alakjában, aki már kívül került az életen, s mégis a fiatalság örömének társává válhatott” (1977: 387; - Gombocz számára az Eötvös Collegium jelentette az ifjúság légkörét).

Pais Dezső egyik aforizmája villan eszembe: „,a tudomány az életért van - és a mi életünk legyen a tudományért!". E nagy igazság mellett van azonban egy másik is. Egy ezt az igazságot nem érvénytelenítő nagyobb igazság. Erre döbbenhetett rá Gombocz legvilágosabban akkor, amikor 1932-ben brutálisan ijesztő figyelmeztetés, első szívinfarktusa érte (NÉMETH 1972: 239). Ez a nagyobb igazság pedig így hangzik: ,a tudománynál az élet többet ér" (SŐTÉR 1976: 120). 


\section{Hivatkozott irodalom}

BENKŐ LORÁND 1954. Egy hangfestő igecsoport. Magyar Nyelv 50: 254-274.

BENKÖ LORÁND 1962. Az új magyar etimológiai szótár. Magyar Nyelv 58: 261-294.

BENKÖ LORÁND 1977: Gombocz Zoltán szerepe a magyar történeti nyelvészetben. Magyar Nyelv 1977: 402-409.

BENKÖ LORÁND 2010. Magyar nyelvtudósok a XX. században. Méltatások, emlékezések. Argumentum Kiadó, Budapest.

FEHÉR KRISZTINA 2011. Gombocz Zoltán mint európai nyelvész. Magyar Nyelv 107: 72-78.

GARAI IMre 2014. A tanári elitképzés mühelye. A Báró Eötvös József Collegium története 1895-1950. ELTE Eötvös József Collegium, Budapest.

GOMBOCZ ZoltÁN 1898. A jelenkori nyelvészet alapelvei [1]. Magyar Nyelvör 27: 6-13.

GomBocz ZolTÁN 1910. Pótlékok a Magyar tájszótárhoz. Összeállította GoMBocz ZolTán. A Magyar Nyelvtudományi Társaság Kiadványai 11. Magyar Nyelvtudományi Társaság, Budapest.

GOMBOCZ ZoLTÁN 1913. Hangutánzás és nyelvtörténet. Magyar Nyelv 9: 385-391.

GOMBOCZ ZoLTÁN 1934. Funkcionális nyelvszemlélet. Magyar Nyelv 30: 1-7.

HARMATTA JÁNOS 1977. Megemlékezés Gombocz Zoltánról. Magyar Nyelv 73: 392-395.

HARMATTA JÁNOS 2002. Gombocz Zoltán mellszobra előtt. Magyar Nyelv 98: 238-240.

HEVESI ANDRÁs 1935. Gombocz Zoltán. Nyugat 28/6: 488-490.

KICSI SÁNDOR ANDRÁs 2006. Gombocz Zoltán 1877-1935. Életrajz és pályakép. ELTE Eötvös József Collegium, Budapest.

Kiss LAJos 1995. Melich János. Akadémiai Kiadó, Budapest.

KOROMPAY H. JÁNOS 2011. Horváth János és Kodály Zoltán barátságának dokumentumai. In: CsISZÁR GÁBOR - DARVAS ANIKÓ szerk., Klárisok. Tanulmánykötet Korompay Klára tiszteletére. [ELTE BTK] Magyar Nyelvtörténeti, Szociolingvisztikai, Dialektológiai Tanszék, Budapest. 17-28.

KóSA LÁSZLÓ 2007. Gombocz Zoltán szobrának avatására. Magyar Nyelv 103: 106-108.

KosÁRY DOMOKOS 2002. Gombocz Zoltán emlékezete. Magyar Nyelv 98: 240-242.

KosZtoláNYI DEZsŐ 1925/1996. Gombocz Zoltán. Pesti Hírlap 1925. június 14. (Újraközölve: Magyar Tudomány 1996/3: 330-332.)

KovAlOVSZKY MiKLÓs 1955. Gombocz Zoltán. A Magyar Nyelvtudományi Társaság Kiadványai 91. Magyar Nyelvtudományi Társaság, Budapest.

LAKÓ GYÖRGY 1977. Gombocz Zoltán finnugor nyelvészeti és östörténeti munkássága. Magyar Nyelv 73: 427-434.

MELICH JÁNOS 1936. Gombocz Zoltán emlékezete. Magyar Nyelv 32: 65-86.

MTsz. = SZINNYEI JózSEF, Magyar tájszótár 1-2. Hornyánszky, Budapest, 1893-1901.

NÉMETH GyUla 1972. Gombocz Zoltán. Akadémiai Kiadó, Budapest.

SAUVAGEOT Aurélien 1988. Magyarországi életutam. Európa Könyvkiadó, Budapest.

SimONCSICs PÉTER 2005. Paradigmaváltás légüres térben. Tinta Könyvkiadó, Budapest.

SÖTÉR ISTVÁN 1976. Évgyürük. Új Írás 16/2: 120.

SÖTÉR ISTVÁN 1977. Gombocz Zoltán. Magyar Nyelv 73: 387-389.

SzamSz. = CsüRY BÁLINT, Szamosháti szótár 1-2. Budapest, Magyar Nyelvtudományi Társaság, $1935-1936$.

TOMPA JóZSEF 1977. Gombocz Zoltán a tanítvány szemével. Magyar Nyelv 73: 409-414.

ZSIRAI MiKLós 1935. Gombocz Zoltán. Nyelvtudományi Közlemények 49: V-XVI.

KISS JENÖ

Eötvös Loránd Tudományegyetem 